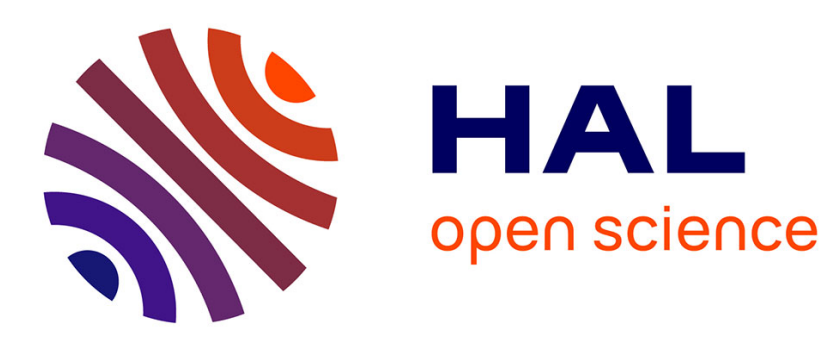

\title{
Olivine-Wadsleyite Transformation within the Subducting Pacific Slab in Kuril
}

Jiaqi Li, Min Chen, Thomas P. Ferrand

\section{To cite this version:}

Jiaqi Li, Min Chen, Thomas P. Ferrand. Olivine-Wadsleyite Transformation within the Subducting Pacific Slab in Kuril. vEGU21: Gather Online, Apr 2021, Online, France. 10.5194/egusphere-egu2113913. hal-03554476

\author{
HAL Id: hal-03554476 \\ https://hal.science/hal-03554476
}

Submitted on 3 Feb 2022

HAL is a multi-disciplinary open access archive for the deposit and dissemination of scientific research documents, whether they are published or not. The documents may come from teaching and research institutions in France or abroad, or from public or private research centers.
L'archive ouverte pluridisciplinaire $\mathbf{H A L}$, est destinée au dépôt et à la diffusion de documents scientifiques de niveau recherche, publiés ou non, émanant des établissements d'enseignement et de recherche français ou étrangers, des laboratoires publics ou privés. 
EGU21-13913, updated on 03 Feb 2022

https://doi.org/10.5194/egusphere-egu21-13913

EGU General Assembly 2021

(c) Author(s) 2022. This work is distributed under

the Creative Commons Attribution 4.0 License.

\title{
Olivine-Wadsleyite Transformation within the Subducting Pacific Slab in Kuril
}

\author{
Jiaqi $\mathbf{L i}^{1}$, Min Chen ${ }^{1,2}$, and Thomas P. Ferrand ${ }^{3}$ \\ ${ }^{1}$ Department of Computational Mathematics, Science and Engineering, Michigan State University, East Lansing, Michigan \\ 48824, USA \\ ${ }^{2}$ Department of Earth and Environmental Sciences, Michigan State University, East Lansing, Michigan 48824, USA \\ ${ }^{3}$ Institut des Sciences de la Terre d'Orléans, UMR-7327, Université d'Orléans / CNRS, Orléans, France
}

At the top of the mantle transition zone, it is commonly accepted that olivine (a) transforms to wadsleyite $(\beta)$ at about $410 \mathrm{~km}$ depth under equilibrium conditions, i.e., a pressure of $\sim 14 \mathrm{GPa}$ and a temperature of $\sim 1350{ }^{\circ} \mathrm{C}$. The subsequent wave speed increase upon the $\alpha-\beta$ phase transition leads to the discovery of the $410-\mathrm{km}$ discontinuity as a global feature seismologically. However, the complex topography of the "410-km discontinuity" is unclear within cold subducted oceanic lithospheres sinking into the lower mantle, partly due to the sparsity of seismic waves sampling the pertaining complex 3-D structures.

This study uses triplicated $\mathrm{P}$ waves ( 2 seconds), most sensitive to the $410-\mathrm{km}$ discontinuity, to invert for the characteristic parameters of its depth and radial wave speed gradients near the discontinuity. Six distinct wave propagation directions are investigated for a carefully chosen earthquake. These directions are sub-parallel to the slab depth contours in the Kuril subduction zone to guarantee a simplified layered earth modeling. Our results show azimuthal variations of the discontinuity depth either above or within the slab.

For example, the $410-\mathrm{km}$ discontinuity is uplifted by $5-10 \mathrm{~km}$ at a depth of about $100 \mathrm{~km}$ above the slab upper interface. The uplift increases up to $15-20 \mathrm{~km}$ when the $410-\mathrm{km}$ discontinuity is closer to, i.e., only $50 \mathrm{~km}$ above, the cold slab. This observation is consistent with the expected phase transition in equilibrium with temperatures greater than $1000^{\circ} \mathrm{C}$. In contrast, within the cold slab $\left(<1000^{\circ} \mathrm{C}\right)$, the $\alpha-\beta$ transition exhibits drastic variations of P-wave speed. Our non-gradient-based inversion results show optimal models that place the following unique seismic constraints: 1) a significant $P$-wave speed increase within the slab $(+5.5 \pm 1.5 \%)$ compared to the ambient mantle; 2$)$ a zone of extremely low wave speed (LVZ) within the slab with a P-wave speed reduction of $-14 \pm 4$ $\%$. The observed LVZ is located near a depth of $350 \mathrm{~km}$ with an apparent thickness of $15-30 \mathrm{~km}$, which can be much thinner in the direction normal to the slab upper interface.

These observations indicate a layer of destabilized olivine (LVZ) exists inside the slab. The $a-\beta$ transition involves atomic diffusion highly dependent on temperature. Once olivine becomes unstable within a cold wedge, it cannot directly transform into wadsleyite. The drastic P-wave speed reduction is likely caused by the sudden grain-size reduction induced by the phase 
transition, and possibly also by the transient (meta)stability of an intermediate phase, the $\omega$ olivine, under substantial shear stress during the transformation within the cold wedge of the sinking slab. 